\title{
Pseudo Thinking of the Social Arithmetic: A Case Study
}

\author{
Lathifah Rahmi ${ }^{1}$, Sufyani Prabawanto ${ }^{2}$ \\ \{lathifahrahmi88@upi.edu ${ }^{1}$, sufyani@upi.edu ${ }^{2}$ \} \\ Mathematic Education Departement, Universitas Pendidikan Indonesia, Jl. Dr. Setia Budhi No. 229, \\ Bandung 40154, Indonesia ${ }^{12}$
}

\begin{abstract}
The purpose of this study is to describe the student's error of pseudo thinking of social arithmetic. The subjects were five students of 8th-9th grade. This research is a case study. Data was collected through student worksheets and interviews. The study was conducted were 40 minutes each for five meetings. Students' understanding was evaluated for the first twenty minutes using the social arithmetic problem, and then we carried on the interview for the next twenty minutes. As a result of this study, subjects still experience error thinking based on pseudo thinking theory. The subjects' type of error thinking is including conceptual pseudo thinking and true pseudo thinking on the material of social arithmetic pseudo. The causal factors include that the subjects do not really understand the interpretation of the question, and they do not understand the interpretation of the formula used.
\end{abstract}

Keywords: Pseudo thinking, Social arithmetic.

\section{Introduction}

The process of thinking as the foundation when someone is learning will improve if the one starts to think. Students think as if they were joining the process of thinking, but what the students think does not comply with the process of thinking. The students' right answer is not always derived from the right mindset, because we do not know what the students think [1]. Students focus only in completing and searching for the answer, not to understand whether the answer represents the problem or not [2][3]. This is called a pseudo thinking condition [4].

Pseudo thinking is thinking fictively, which means in solving a problem, it is possible that students do not really think about how to acquire the answer to the problem given [5]. Pseudo thinking is related to one's belief which has not been proven. A lot of philosophers claim that the truth of knowledge is not always in line with belief [6]. Pseudo thinking deserves more attention as one piece of knowledge about the occurrence of error in one's mathematical thinking [7]. Students' error thinking in solving mathematics problems needs attention, if not immediately resolved, the error will have an impact on students' understanding of the next mathematics concept [4].

Error based on the pseudo thinking theory are divided into two views, namely pseudo thinking which was proposed by Vinner based on the process and pseudo thinking proposed by Subanji based on the final result (final answer). Pseudo thinking based on the process is divided into two, namely pseudo conceptual thinking and pseudo analytical thinking [8]. Pseudo conceptual thinking occurs if students in learning are unable to think about a concept, meaning 
and relationship, however, they can yield answers that seem conceptual in solving the problem. Meanwhile, pseudo analytical thinking occurs if students do not act as expected, not complying with the suggested process of thinking in solving problem, and not even find various ways, but can generate an answer that seems to be analytic in solving the problem. Pseudo thinking based on the final result (final answer) is divided into two, namely true-pseudo thinking and falsepseudo thinking [9]. True-pseudo thinking occurs if the students who give a correct answer are unable to provide justification to the answer; the answer is "pseudo truth" or true-pseudo [9]. Meanwhile, false-pseudo thinking occurs if students give a wrong answer but after doing some reflection they can fix it so that it becomes a correct answer.

Pseudo occurs when understanding mathematical problems, where the mathematical ability that is understood is still raw and does not correspond to real conditions [10]. The concept of mathematics learning material is identical to the problems of everyday life, one of which is social arithmetic. Social arithmetic is a frequent subject used in everyday life, at work or for studying other subjects because they discuss a financial calculation in commerce and everyday life along with its aspects [11][12]. Learning activities in social arithmetic are learning activities that go directly to everyday life and in these questions contain story questions in them [13].

Previous research shows that there are students who experience error thinking based on pseudo thinking theory on the concept of fraction [14]. The result of the study shows that students experience pseudo conceptual thinking when students do not understand the need to shading when drawing a fraction, and true-pseudo thinking when the students do not understand the concept of drawing a fraction from the same size and breaking it down to the same number as the fraction denominator, and false-pseudo thinking when students do not understand the problem and the reflection is necessary for the concept of drawing a fraction [14]. There is also research on students' errors based on Newman Stages in social arithmetic material which found that the mistake of the students on the type error I (reading error) of $8.33 \%$, the type of error II (reading comprehension difficulty) of $13.64 \%$, type error III (transform error) of $14.39 \%$, type error IV (weakness in process skill) of $31.82 \%$, error type V (encoding error) of $31.82 \%$ [15]. Thus, this study aims to describe students' pseudo error thinking on other mathematical material concepts, namely the concept of social arithmetic.

\section{Method}

This research is a case study research. Qualitative case study is an approach to research that facilitates exploration of a phenomenon within its context using a variety of data sources [16]. The case in this study is about pseudo thinking and social arithmetic concept. There are 5 children with the range of $8^{\text {th }}-9^{\text {th }}$ grade as subjects. All subjects had previously studied the concept of social arithmetic in $7^{\text {th }}$ grade. The data collected use the student worksheet and interview. Students' answers are analyzed. If there is an answer from a student who has a pseudothinking error in the completion or process step, then during the interview, it will be analyzed whether the student is experiencing pseudo conceptual or pseudo analytic. However, if there is a student's answer who has a pseudo-thinking error in the final result or the final answer, then during the interview, it will be analyzed whether the student is experiencing true-pseudo or false-pseudo. The study is held in five meetings, in 40 minutes for each subject. Students' understanding is evaluated for 20 minutes using social arithmetic problem and interview for 20 minutes. There are 4 social arithmetic problems. The problems were adopted from $7^{\text {th }}$ grade high school mathematics book. 


\section{Result and Discussion}

There are four problems in this research. The focus of the problem is on social arithmetic material. Five subjects selected in this study experienced all kinds of pseudo error thinking, namely pseudo conceptual, pseudo analytic, true pseudo, and false pseudo in social arithmetic material.

\subsection{Problem 1}

A meatball seller spends IDR 1,000,000.00 to run his business. He sets the price of the meatball IDR 8,000 per portion. If he plans to get minimum profit of IDR 250,000.00 from the sale, then what is the minimum portion that should be made?. Problem 1 asks the minimum benefit of the social arithmetic problem being presented. Subjects 1 and 2 could answer problem 1 properly and correctly. Subjects 3, 4 and 5 used a correct concept, but made the same mistake which generated the final result of 156 portions.

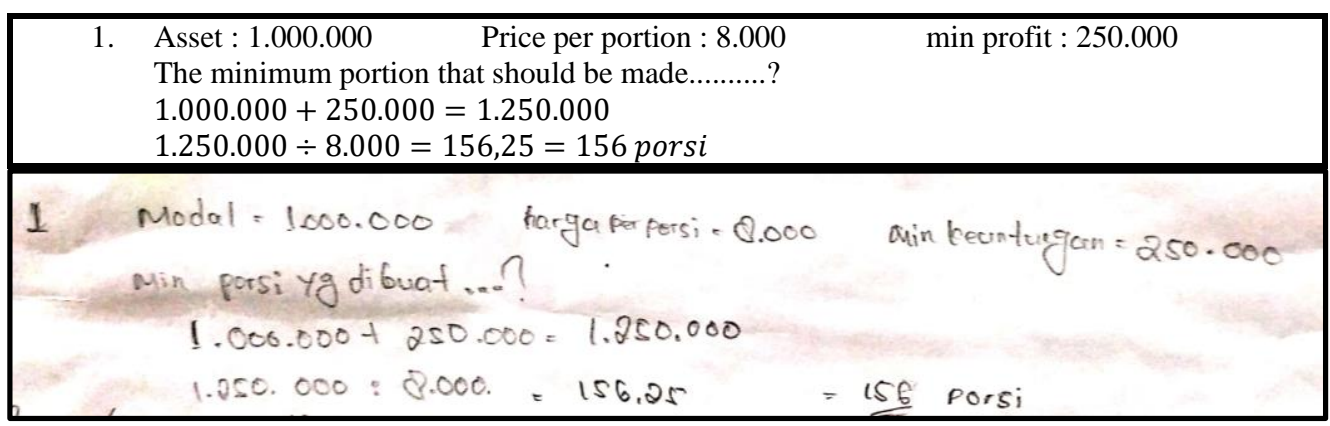

Fig. 1. Subject 3 answer sheet of problem 1

Based on this case, the subject resolves the problem. It is possible that the participant students did not really think about how to get an answer to the given problem [5]. At the time of the interview subjects 3,4 and 5 said the same reason, when they were asked "Why is the answer 156 portions?", The answer from each of them was "because final result obtained is 156.25 and if rounded using the rounding rule it becomes 156 , so the final result is 156 portions". From the result of the test and interview, subjects 3, 4 and 5 were unable to think about the concept of rounding according to the question request. A condition such this is related to the error thinking based on pseudo thinking theory with pseudo conceptual characteristic. In accordance with the explanation that pseudo conceptual thinking occurs when students in learning is not able to think about a concept, meaning and relationship, however they can generate an answer that seems conceptual in solving a problem [8]. So it can be concluded that subjects 3,4 , and 5 experienced the error thinking based on pseudo thinking theory with pseudo conceptual characteristic.

\subsection{Problem 2}

Mr. Iqbal sells a (new) laptop for IDR 4,000,000.00 (without tax). The laptop was purchased by Mr. Ro'uf with a Value Added Tax (VAT) of 10\%. Determine the money which should be paid by Ro'uf (including tax). Problem 2 asks the price of an item that has been taxed on a social arithmetic problem. All subjects correctly solved problem 2 . However, on the interview session 
subject 5 could not answer the question from the researchers about the amount of tax Value Added (VAT).

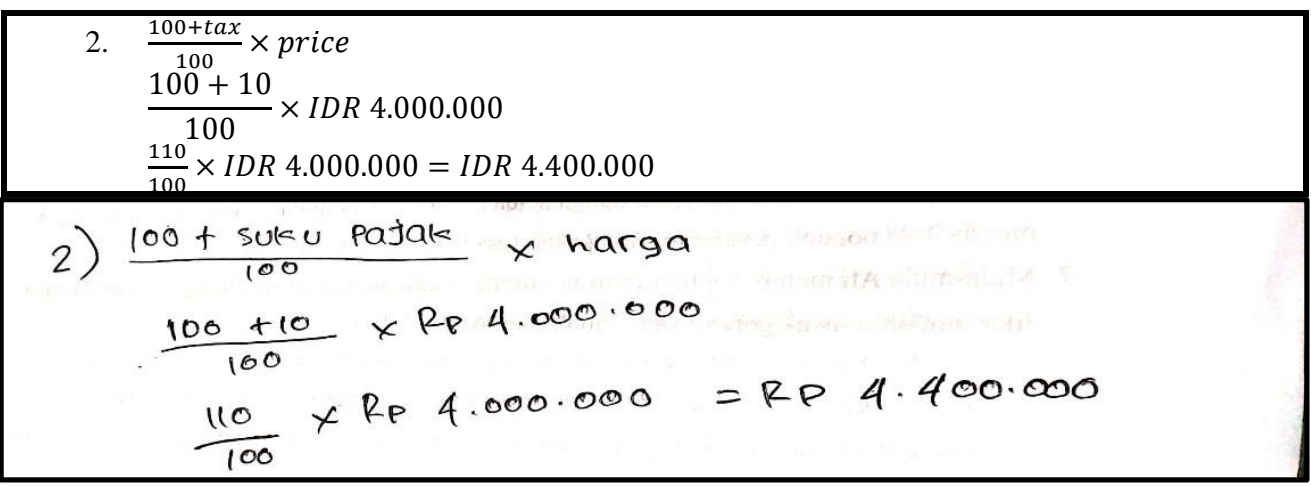

Fig. 2. Subject 5 answer sheet of problem 2

Evaluating from subject 5's answer sheet, he solved problem 2 using the same conceptual method of a formula, but when asked "How much is the Value Added Tax (VAT)?" Subject 5 answered "I don't know the amount of Value Added Tax (VAT), I just know the price for the laptop which is paid by Mr. Ro'uf'. In a condition such this, the subject did not reflect, gave a spontaneous response without realising what was being done, and did not show any encouragement to check the correctness of the answer [8]. From the result of the interview, it can be seen that the subject gave a correct answer but is unable to justify the answer he did [9]. So it can be concluded that subject 5 experienced the error thinking based on the pseudo thinking theory with true pseudo characteristic.

\subsection{Problem 3}

A seller buys clothes from a wholesaler for IDR 30,000. The clothes are sold with a label of IDR $60,000.00$ with a $20 \%$ discount written on it. Determine the seller's profit, say the clothes are sold. Problem 3 question the earned profit after getting a discount in social arithmetic problem. All subjects resolved this problem 3 properly and correctly and with conceptual finishing steps. During the interview, all subjects also answered with a correct answer and understanding. So it can be concluded that all subjects did not experience error thinking based on pseudo thinking theory on this problem 3.

\subsection{Problem 4}

Pak Bagus loaned money from a bank as much as IDR 2,000,000.00. He paid the loan in instalment with a nominal of IDR 100,000.00 per month, for 2 years. Determine the annual interest percentage required by the Bank. Problem 4 is about a social arithmetic problem and questioning the annual interest used by a bank. Subjects 2 , subject 3 , and subject 4 could not answer problem 4 correctly. While subject 1 and subject 5 by pseudo answer. During the interview, subject 1 said that "I can solve this problem". 


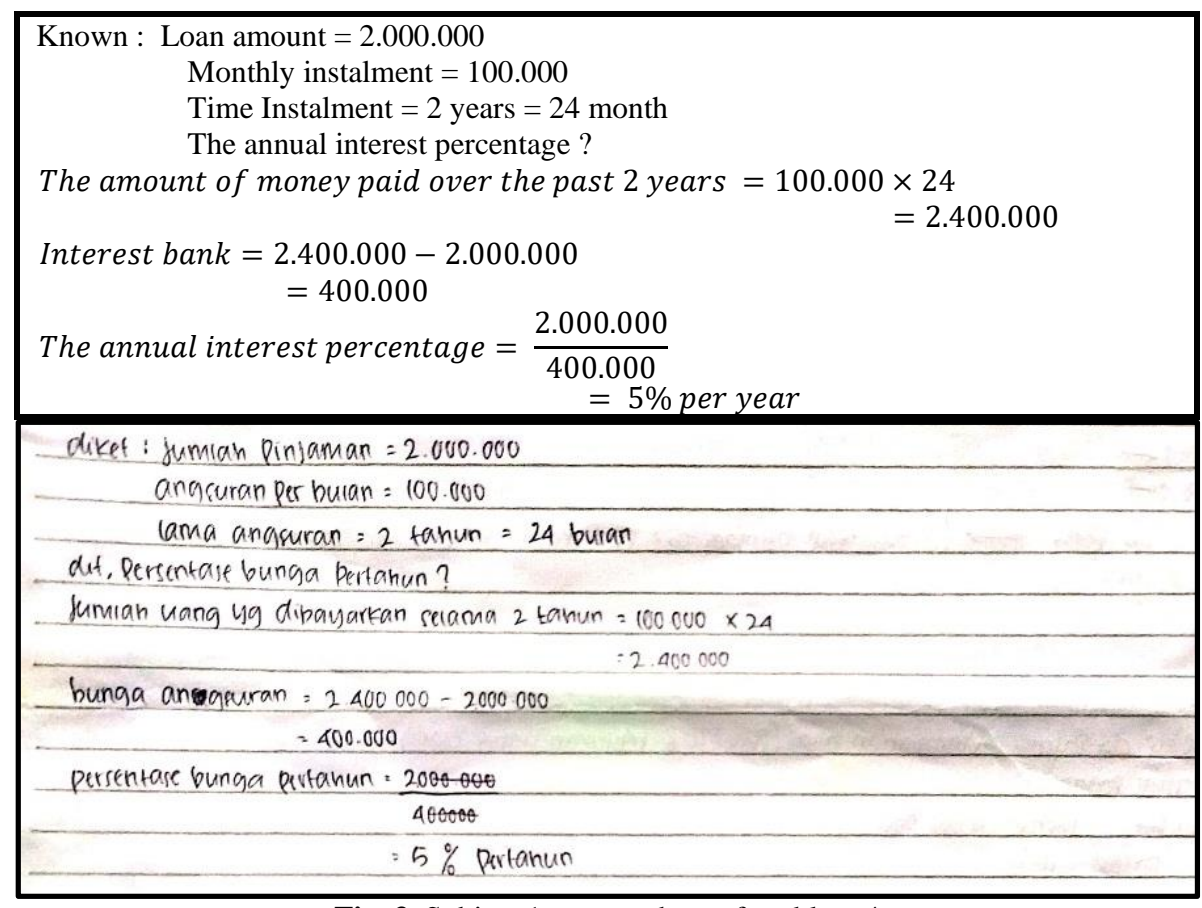

Fig. 3. Subject 1 answer sheet of problem 4

The concept used by Subject 1 is correct. However subject 1 did not realise that the final result he got was the percentage of interest for 2 years, while the question asked about the percentage of interest per year. From the result of test and interview it can be seen that the subject is not capable to think about the meaning of the concept they used [8]. The meaning of the concept that subject 1 used did not show the result of what the question ordered. Hence, it can be concluded that subject 1 experienced error thinking based on pseudo-thinking theory with pseudo conceptual characteristic.

What is written by subject 5 in problem 4 has the same solution but the result is different from subject 1 's.

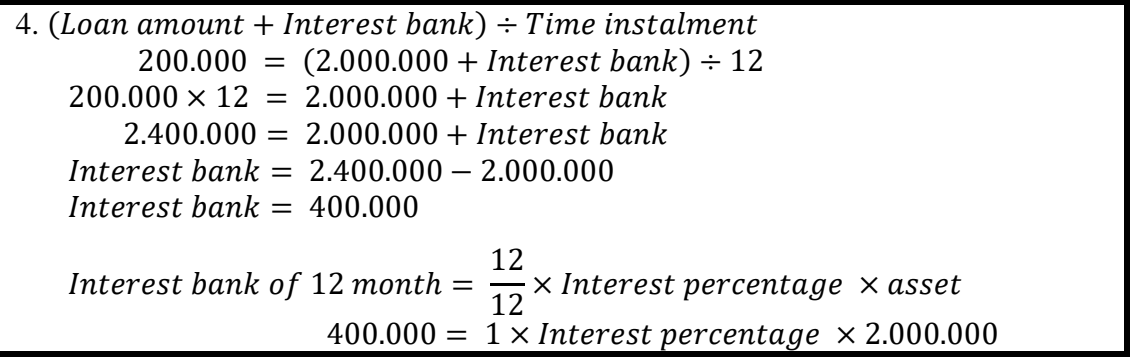




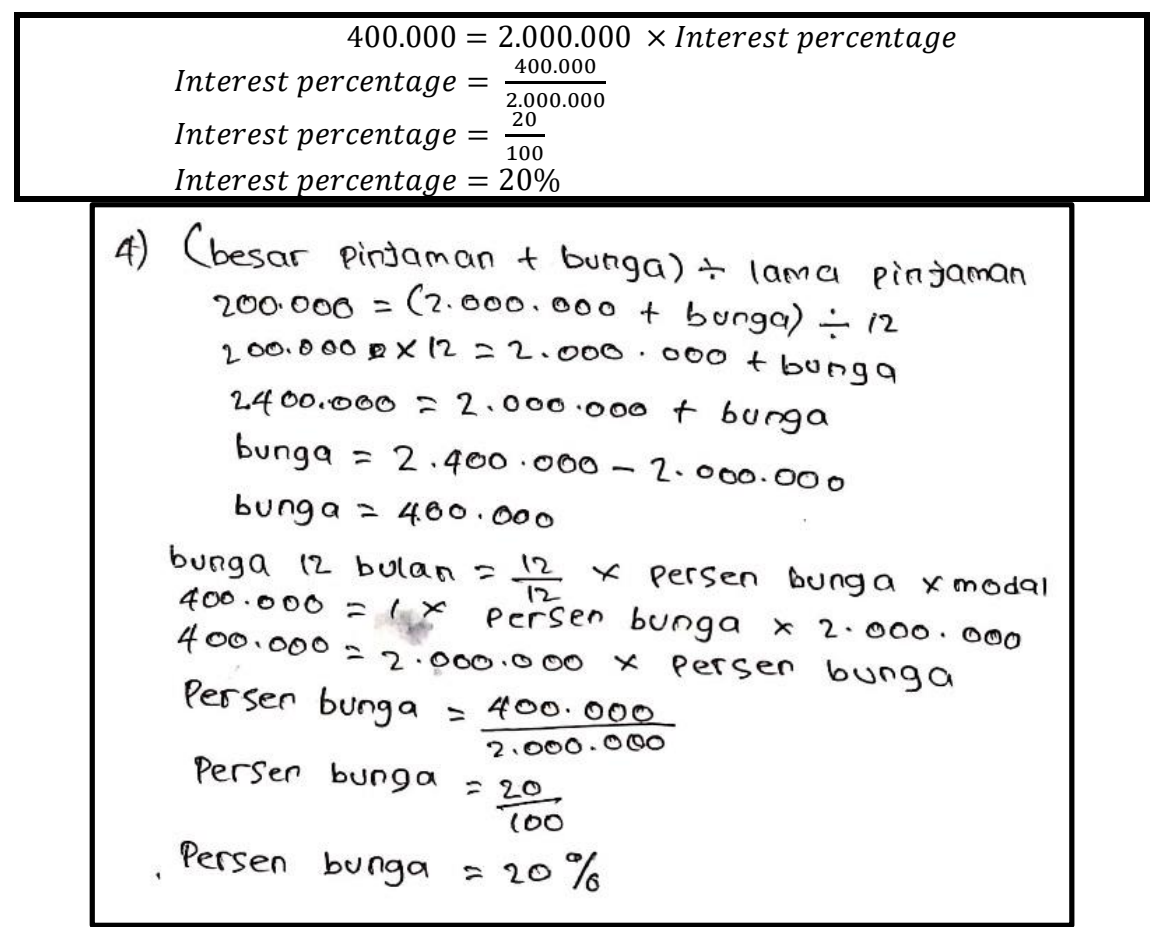

Fig. 4. Subject 5 answer sheet of problem 4

During the interview, subject 5 said "I can solve problem 4 with a formula that I got from the book". The same way as subject 1 , the concept used by subject 5 is already right. However, subject 5 did not realise that the final result he got was a percentage interest for 2 years, while the question asks the percentage of interest per year. From the result of test and interview it can be seen that the subject is unable to think about the meaning of the concept he uses [8]. The meaning of the concept that subject 5 used did not show the result of what the question ordered yet. Hence, it can be concluded that subject 5 experienced error thinking based on pseudo thinking theory with conceptual pseudo characteristic.

\section{Conclusion}

From this research, obtained an overview of students' pseudo thinking mistakes on the concept of social arithmetic. The subjects studied in this study are still experiencing error thinking based on pseudo thinking theory. The type of error thinking experienced by the subjects is including pseudo conceptual thinking and true pseudo thinking in social arithmetic material. The causal factors include that the subjects do not understand the meaning of the question and do not understand the meaning of the formula used. 


\section{References}

[1] Eko Y S, Prabawanto S and Jupri A. The role of writing justification in mathematics concept: the case of trigonometry. Journal of Physic Conference Series. 2018; 1097012146.

[2] Byrne M, Hanusch S, Moore R C, and Fukawa-Connelly T. Student Interpretations of Written Comments on Graded Proofs. International Journal Research in Undergraduate Math. Educ. 2018; 4(2).

[3] Szabo A and Andrews P. Uncovering the Relationship Between Mathematical Ability and Problem Solving Performance of Swedish Upper Secondary School Students. Scandinavian J Educ Research. 2018; 62(4).

[4] Subanji and Nusantara T. Karakterisasi Kesalahan Berpikir Siswa dalam Mengonstruksi Konsep Matematika. Jurnal Ilmu Pendidikan (JIP). 2013; 19(2).

[5] Subanji. Teori Berpikir Pseudo Penalaran Kobarasional. Malang : UM Press; 2011.

[6] Turri J. Is knowledge justified true belief?. Synthese. 2012; 184(3).

[7] Wibawa K A. Karakteristik Berpikir Pseudo dalam Pembelajaran Matematika. Jurnal Pendidikan. 2015; 1(5).

[8] Vinner S. The pseudo-conceptual and the pseudo-analytical thought processes in mathematics Learning Educ Studies in Mathematics. 1997; 34.

[9] Subanji. Proses Berpikir Penalaran Kovriasonal Pseudo dalam Mengkonstruksi Grafik Fungsi Kejadian Dinamika Berkebalikan Disertasi tidak diterbitkan. Surabaya: PPs UNESA; 2007.

[10] Sa'dijah C, Afriyani D, Subanji, Muksar M, and Anwar L. Assessing Students' PseudoMathematical Translation Using Translation-Verification Model. AIP Conference Proceedings; 2018. pp. 1-9.

[11] Muslika. Meningkatkan hasil belajar siswa kelas VII.c SMP Negeri 1 Mumbulsari Jember pada materi Aritmatika Sosial dengan Model React (relating, experiencing, applying, cooperating, Transferring) tahun 2012/2013. Kadikma. 2014; vol 5 p 176

[12] Paramitha and Nandya. Analisis Proses Berpikir Kreatif dalam Memecahkan Masalah Matematika Materi Aritmatika Sosial Siswa SMP Berkemampuan Tinggi. Jurnal Mitra. 2014.

[13] Inayah F F. Penerapan teori Situasi Didaktis pada Materi Aritmatika Sosial. KONTINU: Jurnal Penelitian Didaktik Matematika. 2018; 2(2) pp 35-47.

[14] Alamsyah A, Susiswo S and Hidayanto E. Berpikir Pseudo Siswa pada Konsep Pecahan. Jurnal 1 Pendidikan: Teori, Penelitian, dan Pengembangan. 2019; 4(8) 1060-1070

[15] Susilowati P L and Ratu N. Analisis Kesalahan Siswa Berdasarkan Tahapan Newman dan Scaffolding pada Materi Aritmatika Sosial. Mosharafa: Jurnal Pendidikan Matematika. 2018; 7(1) pp 13-24

[16] Baxter P and Jack S. Qualitative case study methodology: Study design and implementation for novice researchers The qualitative report. 2008; 13(4) pp 544-559 